Article

\title{
When Terror Strikes: The 2015 Paris Attacks in Religious Education Classrooms in Norway
}

\author{
Audun Toft \\ Department of Culture, Religion and Social Studies, University of South-Eastern Norway, \\ 3045 Drammen, Norway; audun.toft@usn.no
}

Received: 7 March 2020; Accepted: 8 April 2020; Published: 21 April 2020

check for updates

\begin{abstract}
Terrorism is commonly considered to be a controversial issue in religious education (RE). RE teachers find it a challenging topic to address, and many avoid it altogether. This article explores the question of addressing terrorism in RE by analysing and discussing empirical observations of RE lessons in an upper secondary school in Norway in the weeks following the terror attacks in Paris in November 2015. Using framing theory, the article discusses aspects of the empirical case study, contextualised by the discussion about controversial issues in education. The main claim of the article is that, rather than seeing the terror attacks as a controversial issue in itself, the terror attacks should be treated as an event that has the potential to tap into several different controversial issues depending on the way it is framed. When addressed in the RE classroom, the teachers actively transform the event into a pedagogical issue, framed in accordance with the nature and aims of the subject. The students, however, often contest this pedagogical framing. This article discusses the interplay between teachers' plans, students' reactions, and the role of media in classroom interaction about the Paris attacks.
\end{abstract}

Keywords: religious education; controversial issues; terrorism; classroom observation

\section{Introduction}

On 13 November 2015, a series of coordinated terror attacks hit Paris. The event ${ }^{1}$ was extensively covered and mediated across the world. Based on empirical material from a case study of religious education (RE) in an upper secondary school in Norway, this article discusses how the attacks were thematised in lessons about Islam in the weeks following the attacks. The analysis is contextualised using ongoing research on controversial issues in RE, and this article aims to further contribute to this debate by providing an empirical case of how a particular controversial event was brought into the RE classroom.

The Paris attacks are an example of an event that can be seen as a controversial issue in schools generally and in RE specifically. Although, and this is an important distinction, the event is not an issue in its own right, the occurrence of concrete terrorist attacks in Europe has been prominent across policy documents and research articles addressing the place of controversial issues in education (see e.g., Anker and Von der Lippe 2018; CoE 2015; DfE 2015, p. 8; Flensner 2019). Lately, there has been an increase in focus on such issues at a policy level both internationally and in different national settings. In 2015, the Council of Europe (CoE) published a "training pack" aimed at teachers and "designed to support and promote the teaching of controversial issues in schools in Europe" (CoE 2015 , p. 7). The authors point out that controversial issues, among which extremism and terrorism are

1 In this article, I will refer to the attacks as a single event. As the empirical data show, details about the attacks were not addressed in the observations, and the attacks were treated as one incidence of terror. 
mentioned explicitly, are seen as too challenging to teach for many teachers. According to the Council of Europe, the handling of controversial issues in schools is "a matter of educational urgency", and the background for this is that Europe has seen a number of "high-profile incidents of violence", such as "the 2011 London riots, the 2011 Norwegian hate crimes and the Charlie Hebdo attack in Paris in 2015" (CoE 2015, p. 7). The role of education is emphasised so that young people can develop the means to deal with controversial issues constructively by engaging with "'real-life' issues" in schools (CoE 2015, p. 7).

The lack of a common definition of controversial issues complicates the matter of how they should be addressed in the classroom. From an educational point of view, it is important to acknowledge that there is a distinction between characterising an issue as controversial in general and teaching it as controversial. Teaching a matter as controversial commonly involves an openness to different points of view on the issue, yet this will not always be an acceptable option with all issues on which there is controversy (see Dearden 1981; Hand 2007, 2008). Michael Hand warns about the problems of conflating the two. Using examples from select British publications and online resources in which issues as bullying, prejudices, and racism are seen as controversial while at the same time it is insisted that controversial issues should be taught openly without the teacher endorsing one view over another, Hand urges educators to consider other criteria for deciding what to teach as controversial than whether it is "ordinarily described as controversial" (Hand 2008, p. 214).

The scholarly discussion over such criteria for what should be taught as controversial (cf. Cooling 2012; Hand and Levinson 2011; Hess and McAvoy 2015; Warnick and Smith 2014) is outside the scope of this article. However, the important role of pedagogical considerations involved when bringing in such issues is an important takeaway from the discussion. Choices made concerning teaching strategy and the contextualisation of the issue matter (see e.g., Hess 2005; Ljunggren 2015; Pollak et al. 2018; Stradling 1984). Marie Von der Lippe (2019) offers an interesting perspective when analysing the case of ritual circumcision in the context of controversial issues in RE. She shows that such an issue is influenced by both contextual factors and the ongoing negotiation between various knowledge producers offering very different conceptualisations of the issue. These elements are important to factor in when approaching such an issue in RE. Controversial issues can thus be addressed in different ways, and the choices educators make will impact how students can then engage with these issues. This is also the case when it comes to terrorism (see Flensner 2019; Hess 2009).

The place of "religiously motivated terrorism" in RE has been the object of some debate in Norway. Bengt-Ove Andreassen has voiced the need for thematising conflict perspectives made relevant by "a global situation where religiously motivated terror and fundamentalism is a continuous cause of worry" (Andreassen 2008, p. 1, my translation). Andreassen claims that Norwegian RE is predominantly harmonising and focusing on the positive sides of religion whilst ignoring or downplaying problematic aspects and conflict perspectives. Trine Anker and Marie von der Lippe have done empirical research in secondary schools, showing that the terror attack in Norway in 2011 is rarely thematised and discussed in schools, and thus, their findings give some support to Andreassen's claims (Anker and Von der Lippe 2015). They point out that teachers find this theme challenging, and they are unsure how to address it. My own classroom observations from an upper secondary school in Norway point in another direction. When the subject is Islam, terrorism and extremism are frequently thematised and discussed (Toft 2017, 2018). These findings do not necessarily contradict Anker and Von der Lippe's conclusions. The teachers in my case study also reported that this was a challenging and sensitive issue to address. When they still chose to do it, the massive media coverage of terrorism in various ways related to Islam, was given as the primary reason (Toft 2018). In other countries with similar models of $\mathrm{RE}$ to Norway, terrorism is also considered to be a controversial issue that teachers tend to avoid or at least find challenging to teach and discuss in the classroom (e.g., Flensner 2019; Quartermaine 2016). 


\section{Research Question, Material, and Context}

In this article, observational data collected from a large upper secondary school in the eastern part of Norway in the days after the Paris attacks will be analysed and discussed. The main research question is: how are the Paris attacks addressed in the observed RE classes? In order to answer this question, this article will focus both on the (a) pedagogical considerations of the teachers about whether and how the event should be included in RE lessons and (b) the lessons themselves, including how students react to and engage with the event in the context of RE. This article shows that considerable planning and thought go into how such an event can be framed in accordance with the aims of the subject. In the lessons, though, the students bring in their own interpretations, which often oppose the prepared pedagogical framing of the teacher.

The empirical material of this article was collected as part of a case study of RE in an upper secondary school in Norway during the 2015/16 school year. The entire fieldwork consisted of direct observation of six teachers in eight different classes as well as observations of teachers between classes and in breaks, meetings, and preparation. The classes observed were all in the last year of upper secondary school. The classes thus followed the same curriculum. All the teachers and nine of the students were interviewed using semi-structured interviews. The data are in the form of handwritten field notes and transcribed interviews from 50 observed lessons and 15 interviews, as well as "jottings" from various informal observations and conversations ${ }^{2}$. In this article, data will be limited to select observations in the two weeks immediately following the attacks. Three classes in which the Paris attacks were thematised were chosen strategically for analysis and discussion on the basis of being the lessons where the most complete set of data were available from both the planning phase and the lessons themselves.

Norway has, similar to the models of the UK and Sweden, designed RE as a non-confessionary, integrative subject mandatory to all students regardless of background. All Norwegian students have RE through primary and secondary school. In upper secondary school, religion and ethics is mandatory for programs qualifying for higher education ${ }^{3}$ and takes place during the third year. Students are then about eighteen years of age. The subject focuses on religious and non-religious worldviews, as well as philosophy and ethics. In addition to the given learning outcomes, the curriculum states that the subject "aims to raise awareness and shape attitudes" and "contribute to knowledge on and respect for various religious, views on life and ethical standpoints in local, national and global perspectives" (Utdanningsdirektoratet 2006, p. 1).

\section{Observation}

\subsection{The Teachers}

On the evening of Friday, 13 November 2015, a series of terror attacks at different locations occurred in Paris. The attacks left 130 people dead and 180 wounded. At least eight people were involved in the attacks, although not all of them have been identified. On Saturday 14 November 2015, the organisation IS claimed responsibility for the attacks, pointing out France's involvement in the conflict in Syria as the motive. The event was massively covered in the Norwegian news media, as well as being thematised and discussed on social media.

Monday is the first day of school after the attacks. The teachers' lounge is buzzing with talk about it. A teacher tells me that he read a poem in his French class. Another says that his students brought up the attacks in a geography lesson. The RE teachers are uncertain about how they should approach the attacks in their classes. Most of them are currently covering the topic of Islam, and they agree that

2 For a more detailed discussion of the methodological aspects of the case study, see Toft (2019).

3 Vocational programs do not have RE. 
this is an event that they have to address in RE. Together, they decide to have an "extraordinary team meeting" the next day where they can discuss what to do.

I get to observe the team meeting on Tuesday, 17 November. All six RE teachers are present, and they discuss different ways to approach the event. A major concern is that it would have to be done in a way that fits with the RE curriculum. "We must take care not to make it a social science class", Charlotte says. Guro replies: "But is it really religion, though?" Most of the meeting is spent exchanging ideas for what sort of material they can bring into the lesson to contextualise the event. "There is so much out there", Kari exclaims. "But very little that will work in the classroom". For the rest of the meeting, they discuss what sort of materials they can use, all of it from the mass media. A documentary about radicalisation by Deeyah Khan is viewed as especially promising, but different op-eds, news pieces and articles, and clips from various news outlets also come up.

After the meeting, I have a long talk with Charlotte on our way to her RE class. She sums up the meeting for me: "We have very individual approaches to how we should teach about this. Both on what we consider to be central and on how much time we should spend on this. I think it is very important", she says. "First of all, it addresses what's going on in society, it indicates how dynamic religion is, not just things described in a textbook, but something that is happening around us and to us". She tells me that her aim is to address the question of who has the power to define Islam. "Is it worse that IS get to define what Islam is, than Obama defining what it's not", she asks rhetorically. "So you design this as a complete pedagogical package", I ask her. "Yes, this is something we can use in later lessons, with other religions".

Charlotte thus chooses to make the lessons about the power of definition, with the explicit goal to criticise how different interpretations of individuals and groups are often generalised to the religion as a whole. She is a bit concerned about spending too much time on this, so she stresses the need to draw on the broader elements of the subject and use it as a foundation for later lessons. Yet, it needs to be addressed. "I can't just dance around the elephant in the room", she says.

\subsection{Transforming the Event into a Pedagogical Issue}

As the observation shows, all the teachers agree that (a) this is an event that must be addressed in the RE lessons and (b) that this is a sensitive issue that will require careful preparation before it is introduced in the classroom. This is significant, because it gives an example of how such an event can be categorised by professional RE teachers. First, the event is categorised as relevant to RE. Even though Guro questions whether the event can be said to be a religious issue when they discuss how to make it a part of their lessons, everyone immediately recognise this as something that belonged in $\mathrm{RE}$. The same is not the case for the teacher teams of any other subject, including the social sciences. Second, it is categorised as necessary to bring into the RE lessons. In the team meeting, the teachers express a sense of urgency and importance related to the event. Even though the teachers openly express uncertainty on how to approach what they see as a controversial and sensitive event in the classroom, and even though most raise concerns about the time constraints of the subject, they agree that it should be made a part of their lessons.

However, they are not in agreement on how this should be done. Noticeably, they have different opinions on how such an event can be the object of an RE lesson. Although the event is seen as relevant, the question of why it is relevant is harder to answer, and the teachers answer it in different ways. None of the teachers suggests addressing the event without properly contextualising it for RE. The perceived controversial nature of the event is also prominent in the discussion and planning of the teachers. In particular, they express concern about how best to introduce the event, and they are unsure about what sort of reactions they should anticipate from the students. All of them plan for controversy in the classroom and have different strategies for how to deal with unexpected and potentially problematic situations.

The different approaches of the teachers highlight an important aspect involved in pedagogical planning. An event in itself does not exist in a form that is directly available for introducing in a lesson. 
Rather, unless the plan is just to have a completely open discussion ${ }^{4}$, such a thematisation involves a series of choices about how the event can be made part of an RE lesson. In other word, the event will need to be transformed into a pedagogical issue, meaning that the event is formatted to open opportunities for learning according to the specific aims and standards of the subject. The process of transforming the event into a pedagogical issue involves a planning stage that includes considerations about, among other things, (a) how the event is framed, (b) what elements to include, (c) what learning outcomes are intended, and (d) the anticipated reactions of the students.

\subsection{Three Lessons about Paris}

\subsubsection{Charlotte's Lessons-Tuesday, 17 November 2015}

As seen above, Charlotte's aim is to use the event to say something about who gets to define a religion. She sees this as a core competence to understanding religion, and she hopes to lay a foundation she can use when dealing with other religious traditions. The planned structure consists of five parts: (1) First, there is an open classroom discussion; (2) next, everyone searches online for different statements about Paris and Islam, and these statements are discussed in class; (3) then, a newspaper article about the silent majority (Muslims who are opposed to the extremist interpretations of Islam) is read aloud and discussed; (4) the class then perform an online search on the word "jihad" and discuss the definitions found; (5) and finally, a documentary is shown and is the object of the final discussion.

Although the lesson is heavily structured and the teaching is directed towards discussing the question of who gets to represent Islam and Muslims, the students bring in a range of different themes for discussion: bombings in Lebanon, the hijab ban in France, and the role of France in the conflict in Syria, as well as the claim that the passport of one of the terrorists was fake and planted to shift blame to IS. Charlotte struggles to keep the discussion on what she has planned to be the main topic of the lesson": "Now we are moving off topic, so I need to moderate", she interjects at one point. "What is interesting here, and there is a lot of public debate over this, is whether this is about Islam. Is it about power? Is it East against West? What is the core"? At this point, she moves the discussion over to the question of who gets to define Islam, and the rest of the time is spent on various approaches to this discussion. The students are active and participate in a lively manner in the discussions about the power to define Islam once this is firmly established as the issue for discussion.

\subsubsection{Kari's Lessons—Wednesday, 18 November 2015}

I observe Kari's RE lessons on Wednesday, 18 November. The day before, Kari had the class in another subject, and the Paris attacks came up. Some students asked if they could talk about it in class. Knowing that they would have RE the next day, she told them that this would be the best context for the discussion. On Wednesday, Kari has decided to use one forty-five-minute lesson to discuss the event. Her main pedagogical aim is to have a discussion in which the students get to voice their opinions and discuss them openly. The topic of the discussion, however, was already decided. She addresses the class as follows:

"A lot is happening in the world now. We spoke about terror in Paris yesterday, and I thought we should start there today before moving on to facts about Islam. Do you want to say what you are thinking? Can we discuss whether Islam promotes terrorism"?

A boy raises his hand, saying: "I saw a news-guy saying that IS wants us to blame Muslims. That's why they do it". This leads to a heated debate on three positions:

4 Which, of course, is an option. This, however, did not happen in this case.

5 In a break, she told me that she felt a strong need to moderate. She saw some of the discussions surfacing as problematic, especially regarding the planted passport, and she found it challenging to make the transition from the discussion to the next part naturally. 
(a) Religion (and Islam in particular) is dangerous, as religious people read violent texts in a literal way. This position is voiced by three boys that openly identify as atheists, and they quote both the Koran and hadith texts (from internet) and cites blogs, articles, and video clips to show that Islam promotes violence.

(b) The Koran and hadith, when studied in their entirety by scholars, denounce terrorism. There are those that use Islam to legitimise terrorism, but they are mostly not very well schooled in Islam. This opinion is held by three students who self-identify as Muslims.

(c) All religions have texts that can be taken to promote violence. This does not mean that religion is to blame for the actions of different individuals and groups committing acts of terror in the name of their religion. This opinion is mainly voiced by two girls with no openly declared religious affiliation.

The different claims are backed up by quotes and references found online and includes different online versions of the Koran, the Bible, hadith collections, and online encyclopaedias, as well as a range of different articles. At several points during the lesson, Kari takes control of the conversation to ensure that it is kept within the established scope of the discussion. When the time is up, she sums up the discussion in the following way:

"We can ask whether Islam is dangerous. Is religion in general dangerous? Is it dangerous to believe in a god, to believe in something beyond yourself, or are humans dangerous? Is man evil? I think we will move on now".

\subsubsection{Anne Lise's Lesson-Tuesday, 24 November 2015}

Anne Lise waits one week to address the Paris attacks in her RE classes. She tells me that she did not want to teach about this until she was properly prepared, and even now, she feels that her lessons could be more thoroughly planned. However, she needs to do it before too much time passes. She tells me that she plans to let the lessons revolve around the documentary Jihad. A story of the others ${ }^{6}$. The aim of the lessons is to show how Islamist terror in the West is connected to the radicalisation of marginalised youth, and she plans to engage the students in a discussion about the causes of radicalisation. In order to give proper background, she also plans to give a short lecture about Islamism.

Anne Lise: We shall talk about Islamism. What is Islamism? We will view it in light of what happened last Friday. You know what happened?

Boy: Paris.

Boy: And Japan, and Mexico, and Mali, Lebanon.

Girl: Iraq. There's a lot happening. There are bombings everywhere.

Boy: Nature-terror ${ }^{7}$.

Girl: But we only get to hear about what happens in Europe. They are biased.

Anne Lise: What do you think about that? I mostly think about Paris, because that was covered extensively. And several terror threats in and around schools in Norway.

Girl: Facebook is really unfair. They only give the French flag.

6 A documentary about former British jihadists and their way into extremism. The documentary was directed by Deeyah Khan.

7 Referring to an earthquake in Japan. 
This leads to a classroom discussion that touches upon several themes: the unfairness of Western media, the situation in Beirut, the 2011 attacks in Norway, and even the origin of IS. Anne Lise moderates the debate, gently trying to shift focus back to the theme of the lesson: "Do you relate IS to Muslims, to religion"? "If you have read the news, there has been several articles about the motivation of these terrorists. Why do they bomb"? After about $15 \mathrm{~min}$ of discussion, she moves on to the next part of the lessons where she lectures about Islamism: "Afterwards we shall discuss the reasons why young people get radicalised and what we can do about it". After the lecture, she shows the documentary and then invites discussion.

Anne Lise: The terror in Paris, what sort of persons did that?

Girl: Young impressionable boys.

Anne Lise: Yes. We can read in the news that they were French citizens and struggled to be integrated.

Girl: There is this convert I read about, Yousef Assidiq. He's a former extremist who works against extremism. He says it's mostly youth who aren't doing too well and they find security and comfort in these groups. That goes for other extremist groups as well, not only the Muslim ones.

They spend the remaining 90 min discussing and grappling with radicalisation. Anne Lise has prepared several newspaper articles about radicalisation, which are used actively.

\section{The Framing of the Event}

There are three things that stand out across observations. Even though the lessons are very different, (1) the actual event in Paris is not addressed directly even once in any of the classes, (2) the teachers and students do not agree on how to interpret the event, and (3) media materials are actively used to provide and support different understandings and interpretations. These findings illustrate the complexity of addressing such an event in the context of a specific subject, such as religion and ethics. It can also shed some light on terrorism as a controversial issue in RE, and it is worthwhile to further examine these elements.

\subsection{It Is Not about Paris_Framing the Event}

The fact that any description of what actually happened in Paris on the evening of 13 November 2015 is absent in the observed lessons is interesting. Other than references to IS's involvement and the mentioning of an alleged fake passport, the lessons are not really about Paris at all. Rather, the focus of the lessons is on larger issues of which the event could be seen to be an instance. In this context, the Paris attacks can be characterised as a case. The pressing question is how the event should be interpreted: what it is a case of. In order to shed light on how this relates to the question of terrorism and controversial issues in RE, I propose to use framing theory as an analytic framework. Framing theory is multifaceted and has taken a wide range of different forms across disciplines for decades (see Entman 1993; Scheufele 1999). In this article, I will lean on the usage of frames and framing developed within social movement theory by Robert Benford and David Snow (Benford and Snow 2000; Snow and Benford 1988). This use builds on Ervin Goffman's understanding of frames as "schemata of interpretation" that enable us to "locate, perceive, identify, and label ( . . . ) concrete occurrences" (Goffman 1974, p. 21). Frames help us "render events or occurrences meaningful and thereby function to organize experience and guide action" (Benford and Snow 2000, p. 614). Thus, to "frame" something is to provide context to an event or occurrence in such a way that it becomes meaningful. In social movement theory, the focus lies on framing as "an active, processual phenomenon that implies agency and contention at the level of reality construction" (Benford and Snow 2000, p. 614). If we use this 
kind of understanding when analysing the observed lesson, we see that the event itself is secondary to the way it is framed.

The observations show examples of what I will call pedagogical framing. This is a specific form of framing in which the professional (RE) teacher provides a certain interpretation that conforms to, and opens up, a subject-specific understanding and enables a particular engagement with the content in order to reach a set of planned learning outcomes. We see that when the event is introduced by the teachers, it is introduced as part of a larger interpretive frame that gives the students cues to what it means and how they should engage with it. It is also relevant that this particular event is seen as sensitive by the teachers, and they are unsure of how the students will react. As they find it difficult to avoid addressing the Paris attacks, they take care to introduce the event as a proper part of RE. Thus, it is only to be expected that the event in itself fades into the background in the observed lessons. It is the frame that matters. Especially so in this case, where it becomes important for the teachers to have a certain amount of control over how the lessons progress.

\subsection{What Is It about?-Frame Contestation}

An event can be framed in different ways (Entman 2003). In the examples above, the teachers chose different frames to address the Paris attacks. Charlotte presented it as a case of extremists claiming to represent Islam. Kari presented it as a possible case of Islam promoting violence. Anne Lise chose to represent it as a case of radicalisation of marginalised youth. Despite being quite dissimilar, all three frames promote an interpretation of the event that encourages subject-specific learning within $\mathrm{RE}$ and is the result of professional considerations of what is well-suited for an RE lesson.

In Kari's case, the class quickly accepts the frame and proceeds to have a discussion about whether or not Islam (and religion in general) can be said to promote violence. Charlotte's and Anne Lise's lessons, on the other hand, are good examples of how a particular framing is not immediately accepted. Here, several students contest the initial framings. Alternate interpretations of the event are prevalent: it is a case of Western bias in the media, it is a case of a legitimate response to France's participation in the Syria conflict, it is a case of reactions to France's hijab ban, it is possibly a case of a false flag operation, and more. It is obvious that the students are interested in the Paris attacks and have formed a range of opinions about the event.

What we see in the above observations are not differing opinions on a specific issue. Rather, the teachers and students present conflicting interpretations of what the event means and how it should be discussed. In these examples, contestation is on the frame level and can thus be seen as what is commonly referred to as a 'framing contest' (Ryan 1991). In all the lessons, we find an extended period of time where the frame is negotiated, and it is not until one frame is agreed upon that the lesson can proceed along the planned lines. The parts of the framing contest are not on equal footing, as there is an asymmetric power dynamic in the classroom. The teachers have the power to force a specific frame. However, they normally prefer not to. When Charlotte evaluates her lessons, she tells me that she needed to moderate more than she likes. She says: "I needed to moderate. It started to slide in all directions. I wish to avoid that. We are going to address content relevant to the subject". Later, she recounts the lessons to the other teachers: "They were very eager to talk. There were, however, many 'derailings' such as talk about the CIA and on whether IS has the right to bomb France back". These sentiments echo what Anne Lise and Kari tell me. Alternative framings in the classroom are primarily seen as disturbances that derail the topic of the lessons. They are not seen as relevant to the lesson, and thus, the aims and plans of the RE lessons also become the measure for how to speak about the event. Alternative framings are excluded as irrelevant based on the professional considerations of the RE teachers.

\subsection{Media Use_Frame Resonance}

The pedagogical framing of the event thus becomes a primary concern for the teachers so that the event can fill a legitimate space in the lessons, furthering the aims of the subject. The students, on the 
other hand, have their own views and contest the pedagogical framing when they bring in different interpretations of the event. It is striking, though, to see how large a role various media representations play in this frame contestation. This goes for both the teachers and students. Any claim furthering a specific interpretation is backed up by reference to, or use of, media.

In the case of the teachers, the observations show that media representations are used actively in order to promote the pedagogical frame. When Charlotte frames the Paris attacks as a case of different actors trying to hijack the definition of Islam, media representations become crucial. First, she engages the students in searching the online news media for what "different people have claimed about Paris and the role of Islam" ${ }^{8}$. She then introduces a newspaper article in which three Muslim women argue that extremists do not represent ordinary Muslims. The results of the search and the article thus support the pedagogical frame-that this is a question about who gets to define Islam. Even more pervasive is Anne Lise's use of the documentary Jihad. A story of the others. The film focuses on British jihadists and how they were radicalised. The common thread in the stories presented is how marginalised youth are vulnerable to radicalisation. After spending $50 \mathrm{~min}$ on the documentary, Anne Lise introduces an article about radicalisation in Molenbeek ${ }^{9}$. In this way, she links the documentary to Paris, and the rest of the lessons is spent discussing the radicalisation of marginalised youth.

The students also make use of media when they frame the event. Facebook is one of the most important sources for information. Blogs, online newspapers, and talk shows are also presented as sources of various claims. The students do not have these sources ready at hand. However, many google as they speak and then read aloud from the sources when they find them. For instance, the boy in Kari's class who referenced "a news guy" proceeded to find the clip in his Facebook feed. In this way, claims are frequently backed up by media sources.

In framing contests, different frames will have varying degrees of effectivity. The more the frame resonates with the audience, the more likely it is to be accepted. Central to the degree of resonance is the credibility of the frame and its relative salience (Benford and Snow 2000, p. 621). Media sources play an important role in relation to both these factors. When it comes to credibility, both the empirical credibility and the credibility of the source of the frame are affected (Benford and Snow 2000, p. 621). When a media source links the frame to an event "out there", the frame gains credibility. Likewise, when an established media outlet can be sited as a source, the frame is more credible; it is not dependent on the credibility of the student alone. The relative salience of the frame is also important, especially if the frame can be said to have "narrative fidelity" (Fisher 1984). This means that a frame will be more effective if it resonates with established cultural narratives. As I will argue below, this is a common characteristic of media frames employed in unfolding media events.

The prominent role of media frames, representations, and references in establishing what the event is about is striking in the material. They play a key part in both the pedagogical framing of the teachers and in the students' counterframing of the event.

\subsection{The Role of Media}

The Paris attacks can be characterised as a hybrid media event (Sumiala and Valaskivi 2018), meaning an event that, through extensive media coverage, can be said to be created and performed in the media and "in which professional media actors, news media and ordinary social media actors alike contribute to the 'live making and sharing' of the event" (Sumiala et al. 2019, p. 203). In their analysis of the mediation of the Charlie Hebdo attack in January 2015, Sumiala et al. point out that during such a disruptive event "the media is keen to try and find explanations and meanings for what has happened". Given the speed of modern media technology, interpretations will have to be

8 She emphasises that the task was related to Islam. They were to search for claims directly involving Islam. "Not the horrors in themselves, but Islam", she instructed the class.

9 This part of Brussels was covered in the news media as a place where many Muslim youth were radicalised. 
given immediately, even before the events have run their course. This, the authors argue, leads to "accelerated circulation of certain emotions and the reliance on mnemonic schemes that date back to 9/11 and even earlier". In such events, various media (including social media) become part of the event itself and add certain dynamics, such as amplification and framing and performative agency to the conflict covered (Hjarvard et al. 2015, pp. 8-10). The processes of framing involved in the hybrid media event tend to involve established schemes of interpretations that put the event into a larger context that resonates with the audience's understanding of the world. Sumiala and Räisä show how "terrorist news events" are ritualised, following a set of key phases, leading to a naturalisation of "us" and "them" (also "friends" and "foes") and contributing to "a collective mythologisation of terrorism in news media and society at large" (Sumiala and Räisä 2020, p. 422).

The classroom observations show that the media frames are essential when the event is thematised in the lessons. Both teachers and students rely heavily on them for making sense of the event and to back up their own claims. As media are the only available sources of information, the framing of the event in the media becomes important for how it is addressed in the classroom. As we have seen, this does not mean that there is a uniform understanding of what the event means. It does mean, however, that the stock of available frames primarily comes from media representations ${ }^{10}$ - something that is highlighted in the way the teachers actively searched through media representations in order to find something they could use in the lessons.

Even though the media are an integral part of the observed lessons, the pedagogical framing does not conform to the ritualisation observed in hybrid media events. When the event is transformed into a pedagogical issue, it is contextualised according to a different set of standards and practices than those that we find in the media. In this way, we can see that both Charlotte and Anne Lise are counterframing what they see as problematic media representations of the event, even though they use alternative media frames to achieve this. Via careful planning, they seek to avoid the naturalisation of "us" and "them" and the potential generalisations of the relationship between Islam and terrorism, thereby using the event to further subject-specific aims of RE. This does, however, come at the cost of shifting the focus away from the event itself and excluding many of the interpretations of the students.

\section{Conclusions}

In the context of RE, terrorism is a controversial issue (Anker and Von der Lippe 2018; Flensner 2019), at least in the sense that teachers are uncertain about how to address it, that it evokes strong feelings, and that it has the potential to divide a class. This article gives an example of how a particular terror event was brought into RE lessons. The current case study is not a typical case of how terrorism is approached in the RE classroom, however. In this case, the thematisation was prompted by an extraordinary event instead of being a topic that the teachers could plan and execute as part of a larger schedule for the subject. However, such a disruptive event can highlight important aspects involved in addressing terrorism in RE.

The teachers find the Paris attacks to be very challenging to approach. However, their professional opinion is that such an event is both relevant and necessary to thematise in the classroom and that this supersedes their reluctance and insecurity about how to address it. This was most likely influenced by the particular context at the time. In 2015, terrorism was massively covered in the news media. The conflict in Syria, the radicalisation and recruitment of foreign warriors, and several terror attacks in Europe were in various ways put in connection with radical Islamism, making the question of the relationship between Islam and terrorism feel urgent. The observations of this article show how this

10 Media in this context involve more than the established news outlets and mass media. It is interesting to see the role of Facebook as a source of information and interpretation. In Chalotte's lessons, Facebook was presented as the source from which most students first learned about the event, and throughout all the observations, Facebook was frequently cited as a source of both information and specific claims about the Paris attacks. 
tension between the need to address the event and the particular possibilities and constraints of the subject play together.

First, they show that terrorism is not easily defined as a single controversial issue. Rather, it can be framed in many ways, resulting in many different kinds of controversies. Not only do the teachers choose very different approaches, the students also actively contest and negotiate the frame. Second, the multitude of available ways the event can be framed is also what makes such an event legitimate to include in the lessons in the first place. The schedule of a small subject such as religion and ethics is tight, and any content must fit into the overall aims of the subject. Thus, a core task for the teacher is to transform the event into a pedagogical issue, and this process is mainly dependent on the pedagogical framing of the event. I see this as a key task in most educational activity; content and topics for lessons are chosen and framed according to the standards of the particular subject. In the present case, this process of transformation becomes highly visible as a concrete event becomes a case of something else in order to be a legitimate part of RE. Finally, the observations show that media representations and frames play a prominent part when dealing with an event such as this. The mediatised classroom (see Lied and Toft 2018) is not a secluded arena. Rather, media of various kinds are constantly in play, providing resources, facts, opinions, interpretations, and alternative frames, which are continuously present in classroom interactions. The ongoing, public contestation over controversial events such as the Paris attacks extends into the classroom, yet it is engaged with in new ways specific to the particular conditions of RE (cf. Toft 2019).

The present case also suggests that pedagogical framing is affected by how comfortable the teacher is with the topic. With respect to controversial issues for which teachers are uncertain about potential student reactions, the frame can be reinforced by heavy moderation of the classroom discussion. In these cases, the frame provides criteria for what is "relevant" to the discussion and serves as legitimation for efforts to control student responses.

I will end this article by emphasising that educators need to be conscious of the way their pedagogical framing both enables and restrains different approaches. While opening up constructive ways that students can engage with a topic in a way that potentially furthers an overall understanding of religion, the process of pedagogical framing also constrains and limits a range of alternative interpretations of an event in which students are interested. There is a real danger of invalidating such interpretations and thus denying students the opportunity to engage with such issues in a way that they find relevant. On the other hand, the opportunities for using such an event to invite students into different perspectives and discussions that unlock new understandings of the subject clearly show the great potential in including controversial issues in RE, even though it is challenging.

Funding: This research was funded by the Research Council of Norway, grant number 236920.

Conflicts of Interest: The author declares no conflict of interest.

\section{References}

Andreassen, Bengt-Ove. 2008. Konfliktperspektiver I Religionsundervisning Og Religionsdidaktikk: En Bredere Og Bedre Tilnærming Til Religion? Acta Didactica 2: 1-22. [CrossRef]

Anker, Trine, and Marie Von der Lippe. 2015. Når terror ties i hjel: En diskusjon om 22. juli og demokratisk medborgerskap i skolen. Norsk Pedagogisk Tidsskrift 99: 85-96.

Anker, Trine, and Marie Von der Lippe. 2018. Controversial Issues in Religious Education: How Teachers Deal with Terrorism in Their Teaching. In Researching Religious Education. Edited by Friedrich Schweitzer and Reinhold Boschki. Münster: Waxmann Verlag, pp. 131-43.

Benford, Robert D., and David A. Snow. 2000. Framing Processes and Social Movements: An Overview and Assessment. Annual Review of Sociology 26: 611-39. [CrossRef]

Council of Europe. 2015. Living with Controversy: Teaching Controversial Issues through Education for Democratic Citizenship and Human Rights (EDC/HRE). Training Pack for Teachers. Available online: https://rm.coe.int/16806948b6 (accessed on 19 February 2020). 
Cooling, Trevor. 2012. What Is a Controversial Issue? Implications for the Treatment of Religious Beliefs in Education. Journal of Beliefs and Values 33: 169-81. [CrossRef]

Dearden, Robert F. 1981. Controversial Issues and the Curriculum. Journal of Curriculum Studies 13: 37-44. [CrossRef]

Department for Education. 2015. The Prevent Duty Departmental Advice for Schools and Childcare Providers. London: Department for Education.

Entman, Robert M. 1993. Framing: Toward Clarification of a Fractured Paradigm. Journal of Communication 43: 51-58. [CrossRef]

Entman, Robert M. 2003. Cascading Activation: Contesting the White House's Frame after 9/11. Political Communication 20: 415-32. [CrossRef]

Fisher, Walter R. 1984. Narration as a human communication paradigm: The case of public moral argument. Communications Monographs 51: 1-23. [CrossRef]

Flensner, Karin K. 2019. Samma konflikter men olika inramning: Kontroversiella frågor relaterade till Mellanösternkonflikterna i religionskunskap och samhällskunskap. Nordidactica 3: 73-100.

Goffman, Erving. 1974. Frame Analysis: An Essay on the Organization of Experience. New York: Harper \& Row.

Hand, Michael. 2007. Should We Teach Homosexuality as a Controversial Issue? Theory and Research in Education 5: 69-86. [CrossRef]

Hand, Michael. 2008. What Should We Teach as Controversial? A Defense of the Epistemic Criterion. Educational Theory 58: 213-28. [CrossRef]

Hand, Michael, and Ralph Levinson. 2011. Discussing Controversial Issues in the Classroom. Educational Philosophy and Theory 44: 614-29. [CrossRef]

Hess, Diana. 2005. How do teachers' political views influence teaching about controversial issues? Social Education 69: 47-49.

Hess, Diana. 2009. Controversy in the Classroom: The Democratic Power of Discussion. New York: Routledge.

Hess, Diana, and Paula McAvoy. 2015. The Political Classroom: Evidence and Ethics in Democratic Education. New York: Routledge.

Hjarvard, Stig, Mette Mortensen, and Mikkel F. Eskjær. 2015. Introduction: Three Dynamics of Mediatized Conflicts. In The Dynamics of Mediatized Conflicts. Edited by Mikkel. F. Eskjær, Stig Hjarvard and Mette Mortensen. New York: Peter Lang, pp. 1-27.

Lied, Liv I., and Audun Toft. 2018. 'Let Me Entertain You.' Media Dynamics in Public Schools. In Contesting Religion: The Media Dynamics of Cultural Conflicts in Scandinavia. Edited by Knut Lundby. Boston: De Gruyter, pp. 243-58.

Ljunggren, Carsten. 2015. Det Offentliga Rummet. In Kontroversiella Frågor: Om Kunskap Och Politik I Samhällsundervisningen. Edited by Carsten Ljunggren, Ingrid U. Öst and Tomas Englund. Malmö: Gleerups Utbildning, pp. 25-42.

Pollak, Itay, Aliza Segal, Adam Lefstein, and Assaf Meshulam. 2018. Teaching Controversial Issues in a Fragile Democracy: Defusing Deliberation in Israeli Primary Classrooms. Journal of Curriculum Studies 50: 387-409. [CrossRef]

Quartermaine, Angela. 2016. Discussing Terrorism: A Pupil-inspired Guide to UK Counter-terrorism Policy Implementation in Religious Education Classrooms in England. British Journal of Religious Education 38: 13-29. [CrossRef]

Ryan, Charlotte. 1991. Prime Time Activism: Media Strategies for Grassroots Organizing. Boston: South End.

Scheufele, Dietram. 1999. Framing as a Theory of Media Effects. Journal of Communication 49: 103-22. [CrossRef]

Snow, David. A., and Robert D. Benford. 1988. Ideology, frame resonance, and participant mobilization. International Social Movement Research 1: 197-217.

Stradling, Robert. 1984. The Teaching of Controversial Issues: An Evaluation. Educational Review 36: 121-29. [CrossRef]

Sumiala, Johanna, and Tiina Räisä. 2020. 'Our words are stronger': Re-enforcing boundaries through ritual work in a terrorist news event. International Journal of Cultural Studies 23: 422-38. [CrossRef]

Sumiala, Johanna, and Katja Valaskivi. 2018. Introduction: Toward hybrid media events of terrorist violence. Television \& New Media 19: 128-35.

Sumiala, Johanna, Minttu Tikka, and Katja Valaskivi. 2019. Charlie Hebdo, 2015: 'Liveness' and acceleration of conflict in a hybrid media event. Media War \& Conflict 12: 202-18. 
Toft, Audun. 2017. Islam i klasserommet. Unge muslimers opplevelse av undervisning om islam. In Ungdom og Religion. Edited by Ida Marie Høeg. Oslo: Universitetsforlaget, pp. 33-50.

Toft, Audun. 2018. Inescapable Coverage. In Contesting Religion: The Media Dynamics of Cultural Conflicts in Scandinavia. Edited by Knut Lundby. Boston: De Gruyter, pp. 259-77.

Toft, Audun. 2019. Conflict and Entertainment: Media Influence on Religious Education in Upper Secondary School in Norway. Ph.D. dissertation, Norwegian School of Theology, Religion and Society, Oslo, Norway.

Utdanningsdirektoratet. 2006. Lxreplan for Religion og etikk. Fellesfag i Studieforberedende Utdanningsprogram. Oslo: Utdanningsdirektoratet.

Von der Lippe, Marie. 2019. Teaching controversial issues in RE: The case of ritual circumcision. British Journal of Religious Education, 1-11. [CrossRef]

Warnick, Bryan R., and D. Spencer Smith. 2014. The Controversy over Controversies: A Plea for Flexibility and for 'soft Directive' Teaching. Educational Theory 64: 227-44. [CrossRef]

(C) 2020 by the author. Licensee MDPI, Basel, Switzerland. This article is an open access article distributed under the terms and conditions of the Creative Commons Attribution (CC BY) license (http://creativecommons.org/licenses/by/4.0/). 